\title{
CORELATON OF DIETARY HABIT WITH HYPERTENSION IN TRIMESTER III PREGNANT WOMEN AT PUSKESMAS BATU AJI, BATAM CITY
}

\author{
Yani Christina $^{1}$, Meirina Daulay ${ }^{2}$ \\ yanicristina@univbatam.ac.id ${ }^{1}$, meirinadaulay@univbatam.ac.id ${ }^{2}$ \\ Professional Doctor Study Program, Faculty of Medicine, Batam University ${ }^{1}$ \\ Medical Education Study Program, Faculty of Medicine, Batam University ${ }^{2}$ \\ Jl. Abulyatama No 5 - Kota Batam
}

\begin{abstract}
Background : Hypertension is a dangerous disease, especially if it occurs in women who are pregnant. hypertension increases mortality and morbidity in pregnant women. According to the Inter-census Survey Data (SUPAS) in 2015, the maternal mortality rate was recorded at 305 per 100,000 live births, which was caused by hypertension at $13 \%$ (Indonesia KKR, 2017). The purpose of this study was to determine the relationship between diet and the incidence of hypertension in third trimester pregnant women.

Method : The research method used was an analytic survey with a cross sectional approach. Conducted at Puskesmas Batu Aji, Batam City, the study was conducted for 6 months, the population in this study were 206 pregnant women in the third trimester, with a sample of 67 respondents, using the Porposive sampling technique. Data collection using a questionnaire. Data presented in tabular and textual form, data analysis using Chi-square.

Result : The results of the study of 67 pregnant women in the third trimester, found that 45 respondents had hypertension, there were 59 respondents or $(73.1 \%)$ with poor diet. From the Chi-Square test with a limit of significance $(\alpha)=0.05$ and the result of p-value $=0.000$ which means p-velue $<(\alpha)$, it is said that the two variables have a relationship or $\mathrm{Ha}$ is accepted, this means that there is a relationship between eating patterns and events.
\end{abstract}

Conclusion : Hypertension in Trimester III Pregnant Women at Batu Aji Health Center. Suggestions so that respondents and readers can apply a good diet that is obtained in everyday life.

Keywords: Diet, Hypertension, Pregnant women

\section{INTRODUCTION}

Hypertension is one of the global problems that hit the world. According to data from the WHO (World Health Organization) in 2012, there were 839 million cases of hypertension. This case is estimated to be higher in 2025 with 1.15 billion cases or about $29 \%$ of the world's total population. Globally, $80 \%$ of maternal deaths are classified as direct causes of maternal death, namely due to bleeding (25\%), usually postpartum hemorrhage, hypertension in pregnant women (12\%), obstructed labor $(8 \%)$, abortion (13\%) and due to other reasons (7\%) (WHO, 2012)
Hypertension is one of the causes of complications in pregnancy. Hypertension usually occurs in pregnancies over 20 weeks. Incidence of hypertension causes $5-10 \%$ of complications.

in pregnancy and related to the incidence of maternal mortality (MMR). According to the 2015 Inter-census Survey Data (SUPAS), the maternal mortality rate was recorded at 305 per 100,000 live births, which was caused by hypertension of 13\% (Indonesia KKR, 2017)

Hypertension in pregnancy is the presence of blood pressure of 140/90 $\mathrm{mmHg}$ or more after 20 weeks of pregnancy in women, or an increase in systolic pressure of $30 \mathrm{mmHg}$ and 
or diastolic pressure of $15 \mathrm{mmHg}$ above normal values according to Ai Yeyeh Rukiyah, (2010)

The incidence of hypertension during pregnancy (preeclampsia and eclampsia) is one of the main causes of maternal death after infection and bleeding (Hasan, 2007). Based on data from WHO (World Health Organization) in 2005 there were 536,000 pregnant women who died due to hypertension during pregnancy. This incident occurred in almost all over the world. Maternal Mortality Rate (MMR) in Southeast Asia amounted to 35 per 100,000 live births. The results of the WHO report in 2005 also stated that in Indonesia the MMR was classified as high with 420 per 100,000 live births (WHO, 2005).

The results of the 2012 IDHS (Indonesian Demographic and Health Survey) state that during the years 2007-2012 cases of maternal mortality jumped up. In 2012 the MMR reached 359 per 100,000 population or an increase of about $57 \%$ when compared to the condition in 2007 , which was 228 per 100,000 population. This is due to the occurrence of pregnant women (pregnant women with high risk), one of which is hypertension during pregnancy (IDHS, 2012).

The Ministry of Health (Kemenkes) argues that, from the aspect of impact, hypertension is a dangerous disease, especially if it occurs during pregnancy, this condition can have an impact on the death of the mother or the baby who will be born. Another problem with hypertension is that it is rare to find certain symptoms or signs. as an early warning. The incidence of hypertension during pregnancy or preeclampsia is still categorized as high, with a percentage of $12 \%$ of all maternal deaths worldwide (Rohmandkk., 2015).

According to Prawirohardjo (2009), pregnancy can change appetite and diet (cravings), where in general, a pregnant woman's appetite will increase, this is the cause of an unbalanced diet, which can lead to complications, including hypertension in pregnant women. Romauli (2014) several types of foods that can cause hypertension, such as organ meats, salty chips, brains, food and drinks in cans (sardines, corned beef). As for the frequency of eating that can trigger the incidence of hypertension in Romauli's study (2014) It was found that more respondents in the case group had a bad diet, this indicates that $70 \%$ of respondents in the case group ate meat, fatty foods, fried foods, foods containing salt $\geq 3$ times a week.

Diet in pregnant women that is low in potassium and magnesium is one of the triggers for hypertension. Meanwhile, fresh fruits and vegetables are the best sources of potassium and magnesium. The dietary approach to stop hypertension through The Dietary Approach to Stop Hypertension (DASH) is recommended to reduce

blood pressure in pregnant women with hypertension (Siervo, 2015) Diet and dietary regulation carried out by pregnant women with hypertension greatly affect the mother's cardiometabolism. Pregnant women who consume high sugar, high fat and contain excess salt increase the risk of hypertension which will harm pregnant women and their fetuses (Siervo, 2015). According to Hanifa (2009), pregnancy can change food tastes and diet (cravings), where in general the appetite for pregnant women will increase, this is the cause of the diet to become unbalanced so that it can cause complications, including hypertension in pregnant women. the type and amount of food eaten every day by pregnant women also affects the mother's diet. A good diet always refers to balanced nutrition, namely the fulfillment of all nutrients in accordance with the needs and balance. The importance of proper nutrition in accordance with the nutritional needs of pregnant women has not been fully realized by the people of Indonesia. In the first trimester, the nutritional needs of pregnant women are generally the same as those of women an ordinary adult who maintains his health. However, nutritional value must still be considered, given the proliferation of ready-toeat foods and eating patterns that tend to lack nutritional intake and variation and the use of additives (Muliarini, 2010).

Referring to various risk factors for hypertension, it is known that there are 
uncontrollable risk factors such as: age, gender, family history and genetics and controllable risk factors, namely: smoking habits, cigarette consumption, stress, use of cooking, obesity, drinking consumption habits. -alcoholic drinking, consumption of saturated fat, lack of physical activity, use of estrogens and various other factors due to lifestyle (Pusdatin Ministry of Republic of Indonesia, 2014).

Based on the results of related research conducted at the Regional General Hospital dr. Zainoel Abidin in 2014, there were 105 cases of preeclampsia from 2,105 pregnant women (4.9\%). The results of this study, it can be concluded that, preeclamptic delivery mothers have a risk of 26.8 times to suffer from hypertension when compared to women who give birth without preeclampsia (Afridayani, 2016).

According to Sofia and Digi (2010), the factors that influence hypertension are age, medical history and lifestyle. The age factor is because hypertension generally develops between the ages of 35-55 years, the older a person is, the regulation of calcium metabolism is disturbed. The health history factor in 70-80\% of cases of hypertension is in the previous medical history, if you have previously had hypertension, the suspicion that the occurrence of hypertension is now because you have previously had hypertension. The pattern of life here is like daily habits, namely the habit of consuming salty foods where eating salty and fatty foods has the potential to develop hypertension, smoking habits and rarely exercise influence the occurrence of hypertension where harmful chemicals enter the body and are not balanced. with a healthy life

According to research by Sihotang et al. 2015, concerning the Relationship between Diet and Adequacy of Sleep Rest and Incidence of Hypertension in Pregnant Women in the Work Area of the Biromaru Health Center, it shows that there is a relationship between diet and adequate sleep rest with the incidence of hypertension in pregnant women in the Biromaru Health Center work area. And based on the results of a preliminary survey at the
Batu Aji Community Health Center on 10 pregnant women, 6 of them did not know a good diet and 4 of them had hypertension.

Based on the description above, the researchers are interested in conducting a study on the relationship between diet and the incidence of hypertension in third trimester pregnant women

\section{RESEARCH PURPOSES}

This study aims to determine the relationship between diet and the incidence of hypertension in third trimester pregnant women at Batu Aji Health Center, Batam City.

\section{RESEARCH METHODS}

The research method used was an analytic survey with a cross sectional approach. Conducted at Puskesmas Batu Aji, Batam City, the study was conducted for 6 months, the population in this study were 206 pregnant women in the third trimester, with a sample of 67 respondents, using Porposive sampling technique. Data collection using a questionnaire. Data presented in tabular and textual form, data analysis using Chi-square

\section{RESEARCH RESULT}

The results of the study of 67 pregnant women in the third trimester, it was found that 45 respondents had hypertension, and 22 respondents $(32.8 \%)$ had no hypertension.

Of the 67 trimester III pregnant women, there were 59 respondents or $(73.1 \%)$ with a poor diet and 18 respondents $(26.9 \%)$ had a good diet. From the research results, it can be seen from 49 respondents who have a bad diet, there are 41 respondents who have hypertension and 8 respondents who do not have hypertension. Meanwhile, of the 18 respondents who have a good diet, there are 14 respondents who are not hypertensive and 4 respondents who have hypertension.

The result of chi-square analysis obtained pvalue 0,000 which means $p$-value $<0.05$ so that Ho is rejected. So it can be concluded that there is a relationship between diet and the incidence of hypertension in third trimester pregnant women at Batu Aji Health Center, Batam City.

\section{DISCUSSION}


From the results of the researcher, it was found that more than some pregnant women had a diet that was less than 59 respondents or $(73.1 \%)$ higher than the good diet of 18 respondents or $(26.9 \%)$.

This is in line with the theory of Sofia and Digi (2010), which states that lifestyle is also very important in human survival, especially pregnant women so that hypertension does not occur, maintaining good diet and habits can prevent hypertension such as not smoking, eating less. -food is salty and get enough rest. This is in line with previous research conducted by Sihotang et al (2015), concerning "the relationship between diet and adequate sleep rest with the incidence of hypertension in pregnant women in the work area of Biromar Public Health Center." The results of the analysis of the relationship between diet and the incidence of hypertension in pregnant women show that from 41 respondents found that there were 31 people. There are 6 people $(14.63 \%)$ who have hypertension and have a good diet and 25 people $(60.97 \%)$ who are not hypertensive and the results of the analysis of the relationship between sleep rest and the incidence of hypertension in pregnant women show that from 41 people it was found that there were 25 people. those who sleep well. There were 6 people $(14.63 \%)$ having hypertension and 19 people $(46.34 \%)$ who were not hypertensive. Furthermore, there were 16 people who had poor sleep rest, 9 people (21.95\%) had hypertension and 7 people $(17.07 \%)$ were not hypertensive.

According to Hanifa (2009), pregnancy can change appetite and diet (cravings), where in general the appetite for pregnant women will increase, this is the cause of the diet to become unbalanced so that it can cause complications, including hypertension in pregnant women. This is in line with Romauli's research (2014), it was found that the respondents in the case group had a bad diet, this shows that many respondents in the case group ate meat, ate fatty foods, fried foods, foods containing salt $=3$ times a week by $70 \%$.
High blood pressure is a chronic disease condition that is very often found in pregnant women with adulthood or old age. One in 10 pregnant women has the potential to suffer from hypertension during pregnancy. Specifically, the age that has a greater risk factor is in women aged 30-40 years than pregnant women at a younger age. Hypertension in pregnant women can have an impact on the health condition of the mother, fetus or child. Physiologically, babies developing in the womb are supplied with oxygen and nutrients through the blood vessels. High blood pressure can constrict blood vessels in the uterus which results in the slow delivery of oxygen and nutrients from the mother to the baby's body, this condition will have an impact on the slow development of the fetus (Afridayani, 2016)

The results of the study of 67 pregnant women in trimester III found that 45 respondents had hypertension, and 22 respondents $(32.8 \%)$ were not hypertensive. The age of the mother at the time of pregnancy can affect every decision and action in choosing the place of examination and the most important thing is to have food that can affect food-induced hypertension. Likewise with the age of the husband if he is older, the knowledge of all explanations related to how to prevent hypertension will also increase. When viewed from an age perspective, pregnant women with hypertension have an average age of over 35 years. There are other related studies that also show an association of age with the incidence of hypertension during pregnancy and there is a relationship between maternal age and cases of hypertension in pregnancy with age $>35$ years at risk of 2.7 times the occurrence of hypertension during pregnancy compared to younger age.

Based on the theory of Emilia and Harry (2010), if pregnant women improve their diet with nutritious foods and do not pose a risk to pregnancy, then the risk of interference with the mother's body and the fetus can be prevented as early as possible. Because the fetus needs perfect nutrition. consume foods with the right diet, enough fiber, low salt and enough water 
Food patterns that contain preservatives such as canned food, salt, spices excessive flavoring affects the incidence of high blood pressure. Examples of foods that contain sodium are salted snacks such as biscuits and chips (Schonaker, 2015). If more sodium is consumed, it will retain more water so that the plasma volume increases. An increase in plasma volume can lead to an increase in blood pressure, especially when the flexibility of the blood vessels is decreased by atherosclerosis. The American Heart Association (AHA) recommends that sodium intake for 15 adults should not be more than $2400 \mathrm{mg} /$ day, which is the equivalent of one teaspoon of table salt a day (Nocce, 2015)

From this description, it can be concluded that a poor lifestyle will affect the occurrence of hypertension. Based on the researcher's analysis obtained from the questionnaire that many respondents answered based on point number 1 to 7 where pregnant women do not like to consume fruits, prefer to eat foods that contain high salt and sodium such as salted fish and chips and often consume food. fast food, there are also respondents who only like to eat instant food such as instant noodles and bottled drinks

\section{CONCLUSION}

Based on research on 67 trimester III pregnant women, the following results were obtained:

1. Most of the respondents are 59 respondents or $(73.1 \%)$ with a poor diet and 18 respondents $(26.9 \%)$ have a good diet

2. Most of the respondents, as many as 45 respondents, had hypertension, and 22 respondents $(32.8 \%)$ had no hypertension

3 . The result of chi-square analysis obtained pvalue 0.000 , which means $p$-value $<0.05$ so that Ho is rejected. So it can be concluded that there is a relationship between diet and the incidence of hypertension in trimester III pregnant women at Batu Aji Health Center, Batam City.

\section{SUGGESTION}

1. For the Health Office

The research results are expected to be used as information and reference, as reading material for the Health Office so that efforts are made optimally through comprehensive counseling and blood pressure monitoring during ANC in pregnant women.

2. For the Batu Aji Community Health Center The results of this study can be used as a medium of information for health workers at the Batu Aji Health Center, Batam City in providing counseling to pregnant women and monitoring consumption and body weight through integrated programs such as nutrition activities for pregnant women, and KIA.

3. For the Community

This research is useful for pregnant women to be able to increase knowledge about the factors that influence the occurrence of hypertension in pregnant women as well as insight into other factors such as parity, obesity, behavioral or socioeconomic and maternal disorders such as mole hydatid, which affect the occurrence of hypertension in pregnant women.

\section{BIBLIOGRAPHY}

Ai Yeyeh Rukiyah, 2010. Asuhan Kebidanan 4 Patologi. Jakarta : Tim

Arikunto, S. 2013. Prosedur Penelitian Suatu

Pendekatan Praktik. Jakarta : Rineka Cipta.

Anggara Dan Prasinto 2012, Faktor-Faktor Risiko Yang Berhubungan Dengan Kejadian Hipertensi Pada Ibu Hamil Di Poli Klinik Obs-Gin Rumah Sakit Jiwa Prof. Dr. V. L. Ratumbuysang Kota Manado.

Bothamley, 2011. Patofisiologi Dalam Kebidanan. Jakarta : EGC.

Boyce, J. M, Pittet, D. 2011. Infection Control and Hospital Epidemiologi, Guidelines For Hand Hygiene in Health Care

Setting Recommendation of the Health Care Infection Control Practices Advisory Commite and the HICPAC, SHEA, APID, IDS.

Cunningham, FG., et al. 2013. Obstetri Williams (Williams Obstetri). Jakarta :EGC. 
Data Dinas Kesehatan Kota Batam, 2016. Profil Ibu Hamil Kota Batam.

Ditjen Kesehatan Masyarakat, Kemenkes RI, 2016. Kasus Komplikasi Kebidanan Provinsi.

Dewi, Sunarsih. 2011. Asuhan Kehamilan untuk Kebidanan. Jakarta: Salemba Medika.

Devina Juwandari, 2015. Faktor-Faktor Risiko Yang Berhubungan Dengan Kejadian Hipertensi Pada Ibu Hamil Di Poli Klinik Obs-Gin Rumah Sakit Jiwa Prof. Dr. V. L. Ratumbuysang Kota Manado.

Dr. I Putu Kusuma 2012. Faktor-Faktor Risiko Yang Berhubungan Dengan Kejadian Hipertensi Pada Ibu Hamil Di Poli Klinik Obs-Gin Rumah Sakit Jiwa Prof. Dr. V. L. Ratumbuysang Kota Manado.

Dr. Susan Redline 2016. Faktor-Faktor Risiko Yang Berhubungan Dengan Kejadian Hipertensi Pada Ibu Hamil Di Poli Klinik Obs-Gin Rumah Sakit Jiwa Prof. Dr. V. L. Ratumbuysang Kota Manado.

Fadlun, 2013. Asuhan kebidanan patologis. Jakarta: Salemba Medika.

Fani Minawati 2015. Faktor-Faktor Risiko Yang Berhubungan Dengan Kejadian Hipertensi Pada Ibu Hamil Di Poli Klinik Obs-Gin Rumah Sakit Jiwa Prof. Dr. V. L. Ratumbuysang Kota Manado.

Harefan Dan Yabesman 2004. Faktor-Faktor Risiko Yang Berhubungan Dengan Kejadian Hipertensi Pada Ibu Hamil Di Poli Klinik Obs-Gin Rumah Sakit Jiwa Prof. Dr. V. L. Ratumbuysang Kota Manado.

Impey, 2008, Obstetrics dan Gyenaecology. Jakarta: EGC.

Karata, 2006. Faktor-Faktor Risiko Yang Berhubungan Dengan Kejadian Hipertensi Pada Ibu Hamil Di Poli Klinik Obs-Gin Rumah Sakit Jiwa
Prof. Dr. V. L. Ratumbuysang Kota Manado.

Langelo, dkk 2013. Hubungan terjadinya Umur dengan kejadian Hipertensi.

Lumoindong, dkk 2013. Hubungan terjadinya Umur dengan kejadian Hipertensi.

Lawrence, G. 2009. Health Program Planning, Educational and Ecological Approach,Mayfield Publishing Company : Calfornia.

Miller. 2007. Faktor Resiko Terjadinya Hipertensi. Jakarta : Rineka Cipta

Nelawati Demanshes, 2014. Faktor-Faktor Risiko Yang Berhubungan Dengan Kejadian Hipertensi Pada Ibu Hamil Di Poli Klinik Obs-Gin Rumah Sakit Jiwa Prof. Dr. V. L. Ratumbuysang Kota Manado.

Notoatmodjo, Soekidjo. 2010. Ilmu Prilaku Kesehatan . Jakarta: Rineka Cipta.

\begin{tabular}{ccr} 
& 2009. & Metodologi \\
\hline Penelitian Kesehatan. & Jakarta: & Rineka
\end{tabular} Cipta.

2010. Metodologi Penelitian Kesehatan. Jakarta: Rineka Cipta.

Paramtisari, 2005. Faktor-Faktor Risiko Yang Berhubungan Dengan Kejadian Hipertensi Pada Ibu Hamil Di Poli Klinik Obs-Gin Rumah Sakit Jiwa Prof. Dr. V. L. Ratumbuysang Kota Manado.

Pesta Corry Sihotang dkk. 2015. Hubungan Pola Makan dan Kecukupan Istirahat Tidur dengan Kejadian Hipertensi pada Ibu Hamil di Wilayah Kerja Puskesmas Biromaru.

Pranama, 2012. Faktor-Faktor Risiko Yang Berhubungan Dengan Kejadian Hipertensi Pada Ibu Hamil Di Poli Klinik Obs-Gin Rumah Sakit Jiwa Prof. Dr. V. L. Ratumbuysang Kota Manado. 
Prawirohardjo,S., 2009. Ilmu Kebidanan. Jakarta: Yayasan Bina Pustaka Sarwono Prawirohardjo.

Pudiastutu, 2012. Asuhan Kebidanan Pada Ibu Hamil Normal dan Patologi. Yogyakarta : Nuha Medika.

Rozinka, 2007. Faktor-Faktor Risiko Yang Berhubungan Dengan Kejadian Hipertensi Pada Ibu Hamil Di Poli Klinik Obs-Gin Rumah Sakit Jiwa Prof. Dr. V. L. Ratumbuysang Kota Manado.

SDKI (Survey Demografi dan Kesehatan Indonesia), 2012

Sirait A.M, 2012. Faktor-Faktor Risiko Yang Berhubungan Dengan Kejadian Hipertensi Pada Ibu Hamil Di Poli Klinik Obs-Gin Rumah Sakit Jiwa Prof. Dr. V. L. Ratumbuysang Kota Manado.

Sofia dan Digi 2010, Hidup Bahagia dengan Hipertensi. Jogjakarta : A Plus Book.

Sarwono. 2006. Metode Penelitian Kuantitatif dan Kualitatif. Yogyakarta : Graha Ilmu.

Sugiyono. 2013. Metode Penelitian Kuantitatif Kualitatif Dan $R \& D$. Bandung: Alfabeta.

Tarigan, Henry Guntur. 2008. Membaca Sebagai Suatu Keterampilan Berbahasa. Bandung: Angkasa.

Tanjung. 2011. Preeklampsi dalam Kehamilan. Bandung : CV Alfabeta

Word Health Organisation, 2010. Data Angka Kematian Ibu.

Widyaninggrum, 2014. Faktor-Faktor Risiko Yang Berhubungan Dengan Kejadian Hipertensi Pada Ibu Hamil Di Poli Klinik Obs-Gin Rumah Sakit Jiwa Prof. Dr. V. L. Ratumbuysang Kota Manado 